\title{
Students' Choice of Business Studies as Programme of study: The Case of Senior High Schools in the Wa Municipality
}

\author{
Paul Tongkomah Saayir ${ }^{1}$, Leticia Bosu ${ }^{2}$ \\ ${ }^{1}$ SD Dombo University of Business and Integrated Development Studies, Wa, Ghana: West Africa \\ ${ }^{2}$ University of Cape Coast, Cape Coast, Ghana, West Africa \\ DOI: https://dx.doi.org/10.47772/IJRISS.2021.5333
}

\begin{abstract}
Making a career choice is a major decision phase in every students' life. Students have to consider several factors before making a decision as to which programme to pursue at high school. The purpose for the study was to find out the factors (extrinsic and intrinsic) that influence students' choice of business studies as programme of study in the senior high schools. The study employed descriptive survey design.Using census, 95 students were employed to respond to the survey questionnaire. Data collected were analysed using descriptive and inferential (independent t-test) statistics. The study found self-interest $(M=2.85 ; S D=0.79)$ in the subject and ability to progress $(\mathrm{M}=3.06 ; \mathrm{SD}=0.83)$ in educational career to tertiary institutions as the most influential intrinsic factors students consider in making a decision of programme choice. Thepossibility of getting high pay job after graduation was the most influential extrinsic factor students consider in a making choice of business studies programme. Gender was however, found not to have significant influence on the choice of a programme of study in the senior high school. Based on the findings, it was therefore recommended that the Ministry of Education through National Council for Curriculum and Assessment should place premium on student's interest (selfmotivation in the subject) in designing the business studies curricula at the high school level; Equally, the nursing and teacher training colleges in Ghana should allow all high school business studies graduates equal access to admission.
\end{abstract}

Keywords: Business Studies, High School Students, Career Orientation, Programme of Study and Gender

\section{INTRODUCTION}

A $\mathrm{n}$ investigation into the factors that influence career choice in business studies among senior high school students'is as important and vital as the decision to influence the business profession itself. The profession of business education has beendescribed as one area where the individual develops personal interest largely due to its nature, prospects and family influence (Zakaria, Fauzi \& Hassan, 2012).Business Education has been defined in several ways, most of which highlight its vocational nature. Osuala (2004) explained business education as a programme of instruction which consists of two parts: (1) Office education - a vocational programme of office careers through initial, refresher and upgrading education and (2) General business education - a programme to provide students with information and competences which are needed by all in managing personal business affairs and in using the services of the business. Also,it is a formof vocational education that is directed towards developing the learner to become productive in teaching, paid employment and self-employment (Idialu cited in Amoor, 2010). Business education prepares beneficiaries for gainful employment and sustainable livelihood. It is generally seen as education for and about business. It is an education that provides knowledge and understanding of the economic, financial, marketing, accounting, and management systems and other branches of business endeavour. Hence, education about business prepares students to function intelligently as consumers and citizens in a business economy.

Amoor (2010) noted that business education plays a significant role ineconomic development by providing knowledge and skills to the learners, thereby, enabling them to adequately impart knowledge into others, and handle sophisticated office technologies and information systems. Since the primary goal of business education is to producecompetent, skilful and dynamic business teachers, office administrators and business gaints that will effectively compete in the world of work, it can then be argued that business education is an impetus to national transformation because economic development usually engenders national transformation. Business education primarily centers on preparing people for roles in enterprises such as being an employee, entrepreneur, employer or self-employed to guarantee economic development. The changes in the business environment, world economy, internationalisation and the pace of economic growth have called for greater emphasis on professionals to be developed on various fields of endeavour. In order to meet the needs of economicdevelopment as well as the current developmental challenges, the world requires the services of more experts forresolution, knowledge and innovation (Zakaria, Fauzi\& Hassan, 2012). One of the areas which are concerned directly with these challenges is business education. Thisis because, business education aims at producing competent, skilful and dynamic business graduates who willeffectively utilize knowledge and innovation in tackling these challenges. 
Also, Business education is both vocational and social in nature and has become an integral part of the whole process of general education that helps in confronting developmental challenges (Crews \& Dickerson, 1999). The Business studies programme has subjects such as financial accounting, business management, business secretariaship economics, cost accounting, elective mathematics or French with financial accounting and business management as a distributed core which prepares prospective accountants or business managers into a range of activities such as auditing, accountancy, taxation and consultancy services.

In Ghana, business studies programme over the years is seen as one of the lucrative and easy fields of endeavour to pursue. Most high school students are eager to pursue business studies because it has a wider range of future professional development for the individual. As its objective, the business studies curriculum is aims at training various personnel such as cost and financial accountants, administrators, managers, auditors, financial analyst among others who will have the necessary knowledge and skills to provide services for the country. The recent analysis of student's enrolment in high schools indicates that, there is a dramatic decline in both the numbers and the quality of students pursing business studies programmes at senior high school in Ghana. Some reasons for the decline in the numbers of students are that, the career opportunities of business studies graduates are limited as compared to their counterpants in the sciences and general arts programmes. Also, the study of the business studies programme does not give them the access to further their education tosome tertiary institutions such as the Colleges of Education and the Nursing Training Colleges where they would be trained as teacher or health professionals. (OseiMarfo, 2014)

Making a choice career in business studies involves a lot of influential factors and should be based on some informed knowledge. Various factors influence career choice, especially, in business studies. Some researchers have categorised the factors that influence student's choice of programme into extrinsic and intrinsic, while others believe that the choice of programmes is usually gender-based. Factors such as parents and family advice,study environment, job opportunity, jobsecurity, prestige and family background are among the major players in the choice of careers (Bornaby, 2005; Greenberg \& Baron, 2008; Uyar, 2011; Asuquo, 2011).Asuquo (2011) has argued that unrealistic career choice among business students is largely due to insufficient knowledge and information on the part of these students. Nevertheless, the business profession gives opportunity to aspiring business students on a variety of choices in the circle of the profession and, hence, the desire to take business studies as a career choice by some of these students.

Also, Asuquo (2011), indicated that parents influence, interest of the individual, peerinfluence, prestige as well as opportunities oftenaffect the decision on career choice in business studies.Greenberg and Baron(2008) emphasise that individuals favour occupations in which there is bigger likelihood of opportunities promotion or advancement and would rather avoid occupation in which opportunities are limited or on decline. Kaur and Leen (2007) establish that students' choices of major coursesare influenced by factors such as gender, race, quantitative skills, interest in the subject, expected marketability, performance in major classes, the approachability and teaching reputation of faculty member. On the contrary, Myburgh (2005) revealed that parents, peer groups, relatives, environment and government policies have impact on individuals' career choices. Kim and Markham (2002) conducted a study on business majors at the tertiary level (accounting, finance, general business, management, marketing, management information system and double major). They discovered that the top five reasons for choosing a major were: interest in a career, good job opportunities, "good fit" with respondents' abilities, a desire to run a business some day and projected earnings in the related career. The least selected reasons for choosing a major were the reputation of the major at the university, the perceived quality of instruction, parents' influence, the amount and type of promotional information and the influence of friends.

Auyeung and Sands (2006), conducted a comparative study between Ghana and Australia high school students and found that the choice of business studies career can be attributed to the individual'sdriving force. Motivational factors such as good long-term earning, parental influence, and the nature of teachingthe programme may impact on career choice for Ghanaianstudents. Some studies have shown that parents' educational background, profession and success of family relativesin business environment do have significant influence on the choice of business studies as a field of study among University students (Uyar\& Ali, 2011). Malgwi, Howe and Bornaby (2005) were also of the view that monetary incentive is not the only factor influencing career choice in business studies(accounting).they maintained that factors such as career advancement opportunity, prestige, social status, job security, higher earning potential and variety of choices are among the chief factors that havesignificantinfluenceon career choice of accounting. In a study conducted by Maudline, Crain and Mounce (2000), it was discovered that the role of educators and the faculty was significant in the career choice of accountants. The study identifiedlifestyle, financial security and motivation, nature of work and work roles as indicators of career choice in accounting.

Cohen and Harno (1993)conducted a survey on the factors influencing career choice among tertiary students in Australia and found that non-accounting students regardaccounting as boring and number oriented. Genuinely, no course or subject is in itself boring. It is rather the instructors of the courses who make them appear boring. In this way, a poor instructor is likely to have a negative impact on students in their selection of careers in disciplines. As evidence of this view, Maudline et al. (2000) found that the accounting instructor is 
the most influential factor in the choice of accounting programme. Other factors, according to Maudline et al. (2000) are career opportunities, lifestyle, prestige and usefulness in organisation. Courses which are likely to make the individual unemployed are always at their decline rate as compared to others whose products are always secured even when there is a change in the labour market or demand. However, the effect of age, gender and lifestyle as well as educational instructors and previous knowledge have also been discovered to have influenced career choices.Byrne and Willis (2005) opined that students are more likely to aspire to a career that is held in high esteem by society. In their study, accounting students ranked accounting $5^{\text {th }}$ while non-accounting students ranked accounting $7^{\text {th }}$ among ten professional courses. Okiror and Otabong (2015) revealed that students' choices were based on their perceived availability of career and scholarship opportunities in a given department and the grade point averages marks earned by the student at the time selecting the options.

In addition, various studies have been conducted on the influence of gender on career choice in relation to the choice of programme study in senior high schools. Researchers such as Xiang, Mcbride, Guan and Solomon(2003); Eccls, Wigfield, Harold and Blumenfeld(1993) conducted a study on gender differences in expectancy-related beliefs, and generally the results showed that male students were identified to hold higher ability beliefs and expectancies for success in businessrelated courses than female students. Many factors were identified as the cause of gender differences in pursuing an educational programme. They include social-cultural, economic, biological, environmental and academic factors (Dolado \& Morales, 2009; Pozo\& Stull, 2006; Carbonaro, 2005; Colom\& Lynn, 2004). However, males' academic performance was considered superior to that of females, especially in male-dominated subjects such as mathematics and science because of higher levels of innate spatial ability. At the same time, females' performance was placed above their counterparts in language subjects because of their greater verbal reasoning abilities (Wilberg\& Lynn 1999). One could, therefore, infer that business studies could be male-dominated because of the involvement or inclusion of accounting as a subject.

A closer look at the various factors from various studies conducted indicatesthat self-interest, personal aspirations, values, attitudes and desire, job prospects and satisfaction as well as social environment have been major influential factors for the choice of business studies by senior high school students. However, there are still attempts to find the factors responsible for students' choice of business studies as a programme of study among academicians, accountants and administrators in educational institutions in Ghana, since most of these studies were conducted some years ago and the findings could have been affected by elapse of time. Also, Ghana has recently introduced Free Senior High School System where student's enrolment has improved significantly, could these factors still remain same for the choice of business studies? because the dynamics of changes in the business landscape and curriculum was not consider in the previous studies. In addition, the choice of the programme may also be influenced by other inherent factors apart from these anecdotal analyses and the factors discussed above. It is, therefore, necessary to assess the factors that influence the choice of business studies as a programme of study among senior high school students in the Wa Municipality of the Upper West Region of Ghana.

The overriding purpose of the study was to examine the factors that influence students' career choice of business studies among senior high school students in the Wa Municipality of the Upper West Region of Ghana. To guide the research, the research questions that were posed were: what are the most extrinsic factors that propel senior high school students' choice in business studies as a programme of study; what are the most intrinsic factors influencing senior high school students' choice in business studies as a programme of study? Finally, the hypothesis that guided the study was that 'there is no significant difference between gender (male and female) and the choice of business studies as a programme of study in senior high schools in Ghana.

\section{METHODOLOGY}

The study employed a descriptive survey designwhich aimed at collecting data from thesampled population for the study. The population comprises all final year business studies students in five selected senior high schools in the WaMunicipality of the Upper West Region of Ghana.Census was used to include all 95 final-year students in the selected schools. The number of respondents (business studies students) from each of the five schools was: Wa Senior High School 30 (31.6\%); Islamic Senior High - 20 (21.1\%); T.I.Ahmadiyya Senior High - 20 (21.1\%); Wa Technical Institute - 15 (15.7\%); and St-Francis Xavier Senior High $10(10.5 \%)$.Questionnaire was used in collecting the data from the respondents. Thelikert scale close ended questions were used. The data was processed using SPSS and analysed using descriptive statistics (mean and standard deviation) and inferential statistics(independent t-test). The independent t-test was used to find out if there wasa significant difference between male and female business studies students in their choice of business studies programme.

\section{RESULTS AND DISCUSSION}

\section{Respondents Background information}

The respondents were asked to provide information regarding their age, gender andparents' occupation. The data provided was to give a better understanding of the results obtained.Sixty-seven (67) $(70.5 \%)$ of the students fell within the age bracket of 13-17, twenty-six (26)(27.4\%) fell within 18-22 years,and only two (2) (2.1\%) of the respondents were 23 years and above. This indicates that majority of the studentsfells within the senior high schooling age limit which 
is within the age group which is $13-18$ years. Sixty-five (65)(68.4\%) of the students were males while the remaining thirty (30)(31.6\%) were females. This indicates that the business studies programme was mainly male-dominated. This may be attributed to the fact that it was a calculationdominated programme (e.g. financial accounting, cost accounting, business mathematics, economics and sometimes elective mathematics). This finding supports the conclusion drawn by Wilberg and Lynn(1999) that males' academic performance wasconsidered superior to that of females especially in male-dominated subjects such as mathematics and science because of higher levels of innate spatial ability.

Also, majority of the respondents 40(42.1\%)indicated that their parents were teachers; the parents of $20(21.1 \%)$ of the respondents were farmers; the parents of $10(10.5 \%)$ of the respondents were accountants; and the parents of 25 (26.3) students fall into various categories such as businessmen (sole traders), social workers and health workers. This indicates that parents' influence on their children's choice of business studies programme may be minimal because only a few of the respondents' parents' work relates to business education.

Intrinsic Factors Influencing Student's Choice of Business Studies as a Programme of Study in the Senior High School

The study sought to find out the most influential intrinsic factors that propel senior high school students to choose business studies as a programme of study. In accordance with this, research question one was formulated as, "what are the most influential intrinsic factors that propel senior high school students to choose business studies as a programme of study? To address this research question, various influential factors were designed and administered to the participating students to find out the most influential factors that propel them to take business studies as a programme of study in the senior high school. The means and standard deviations of each of the factors were computed.

Table 1: Intrinsic Factors Influencing Student's Choice of Business Studies as a Programme of Study

\begin{tabular}{|l|l|l|}
\hline & Mean & SD \\
\hline Learning business is very easy for me & 1.80 & 0.60 \\
\hline $\begin{array}{l}\text { Educational progression to tertiary institutions } \\
\text { is varied }\end{array}$ & 3.06 & 0.83 \\
\hline I have self-interest in learning business studies & 2.85 & 0.79 \\
\hline I have good attitude towards business studies & 1.80 & 0.60 \\
\hline The prestige attached to business professionals & 2.73 & 0.73 \\
\hline $\begin{array}{l}\text { My parents' occupation encourages me to } \\
\text { choose business }\end{array}$ & 2.52 & 0.65 \\
\hline
\end{tabular}

Source: Field Survey, 2018

Decision rule: Mean 2.60 and above=most influence

Mean 2.59 and below=less influence

The results displayed in Table 1 indicate that the most important intrinsic factor which influencessenior high school students in their choice of business studies was the availability ofvaried forms of educational progressions to the tertiary institutions. With a mean score of 3.06 and a standard deviation of 0.83 , the majority of the respondents agreed that because of varied form of educational progression that are available to them, they were motivated to choose business studies as a programme of study. Self-interest in learning business studies programme was also rated the second most intrinsic influence on students' choice of business studies programme in the senior high school. With a mean score of 2.85 and a standard deviation of 0.79 , the respondents agreed that self-interest had great influence on their choice of businessstudies as a programme of study. Professional prestige attached to the study of business studies programme was also seen as having an influence on students' choice of business studies programme in the senior high school. This was rated as the third factor that influences student's choice of programme with a mean of 2.73 and standard deviation of 0.73 .

The results also revealed that the easy learning of business studies, good attitudetowards business studies and parents' occupationwere rated as part of the factors that had the least influence on the respondents' choice of programme in the senior high school, although their mean scores and standard deviations varied. The easy learning of business studies and good attitudetowards business studies statements recorded a mean of 1.80 and a standard deviation of 0.60 respectively, while parents' occupation recordeda mean of 2.52 and a standard deviation of 0.65 .

The results in Table 1 indicates that the most influentialfactors of senior high school students' choice in business studies programme is the desireto progress in their educational career to tertiary institutions, including the colleges of education, nursing training colleges, technical universitiesand the traditional universities. Thus, the ability of high school students to pass their final examinations and get admission into tertiary institutions is the topmost priority in making a choice of a programme. This view was affirmed byGreenberg and Baron (2008) who highlighted that individuals favour occupations in which there is bigger likelihood of career opportunities and would rather avoid occupation in which opportunities are limited or on decline. Okiror and Otabong (2015) revealed that students' choices were based on their perceived availability of career and scholarship opportunities in a given department. Also, Malgwiet al. (2005) supported the assertion of the respondents when they indicated that monetary incentive is not the only factor that influences career choice in business studies programme, but other factors such as career advancement opportunity have significant influence on career choice of business studies.

Again, the respondents indicated that they were self-motivated to make a choice of career in business studies programme since the decision to make a choice of a programme is personal.This meant that the choice of business studies programme was largely influenced by the person's own aspirations, values, interest and motivation. Byrne and Willis (2005) supported this assertion that various factors such as self-interest, personal aspirations, values, attitudes and desires 
and satisfaction have been the major influential factors for the choice of business studies by senior high school students. Also, interest in the subject is the most influential factors for college major choice (Malgwi, Howe and Burnaby, 2005; Yazici and Yazici, 2010). Again, Ahmed, Sharif and Ahmad (2017) revealed that interest in subject has strong and positive relationship on students' decision for particular field and subject. The issue of professional prestige was equally considered as an influential factor in choosing business studies programme. This view is affirmed by Maudline, et al. (2000) that the prestige and the programme usefulness in an organisation is one of the influential factors in making choice of a business studies programme. In addition, Willis (2005) indicated that students are more likely to aspire to a career that is held in high esteem by society. Furthermore, the assertion of professional prestige was collaborated byAsuquo (2011) when he indicated that the prestige attached to a programme often affect the decision on career choice of business studies programme. The issue ofeasy learning of business studies, good attitude and parental influence have a little influence on high school students' career choice of business studies since accounting has some level of learning difficulty and alsothe parents of most students have no business studies background and know little about the business profession as seen in the background data of the respondents.

\section{Extrinsic Factors Influencing Student's Choice of Business Studies as a Programme of Study}

The purpose of research question two was to find out the extrinsic factors that influence senior high school students to choose business studies. In accordance with this, research question two was formulated as, "what extrinsic factors mostly influence students to choosebusiness studies as a programme of study in the senior high school?"To address this research question, various factors were designed and administered to the respondents to find out the most influential extrinsic factors that propel them to select business studies as a programme of study in the senior high school. The means and standard deviations of each of the factors were computed. A mean value of 2.60 and above indicates that the factor is highly influential on the high school student's choice of business studies as programme of study. The results of these extrinsic factors that influence high school student's choice of business studies programme are presented in Table 2.

Table 2: Extrinsic Factors Influencing Student's Choice of Business Studies as a Programme of Study

\begin{tabular}{|l|l|l|}
\hline Statement & Mean & SD \\
\hline Peer influence & 3.00 & 0.72 \\
\hline I can get high-pay job after my graduation & 3.32 & 0.82 \\
\hline I can easily get employment after graduation & 3.19. & 0.81 \\
\hline Business studies is a field with a broad exposure & 1.64 & 0.50 \\
\hline Societal influence & 2.57 & 0.67 \\
\hline Parental influence & 2.24 & 0.55 \\
\hline
\end{tabular}

Source: Field Survey, 2018
Decision rule: Mean 2.60 and above=Most influence

Mean 2.59 and below=Less influence

The results in Table 2 revealed that the first extrinsic factorthat influence senior high school student's choice of business studies wasrespondents' anticipation of getting highpay jobs when they graduate from the programme. This factor was the mostinfluential with a mean score of 3.32 and a standard deviation of 0.82 .This meant that the key consideration in making a choice of a programme is the future job prospect and the pay associated with the job. This assertion affirms the views of Auyeung and Sands (2006) who found from their comparative studyof Ghana and Australia that motivational factors such as good long-term earning may have impact on career choice for Ghanaian students. Ghana as a developing nation has slow economic growth and high unemployment rate. Most graduates, therefore, spend more time at school and home waiting to get full-time employment and would, therefore, expect high-pay jobs after completing school in order to begin family life well. Also, Yaseen (2011) in a study of Kuwaiti students identified large salary to be significant factors influencing Kuwaiti student teachers' choice of teaching as a career. Senior high school business studies students anticipate getting high-pay jobs after pursuing a career in business studies to enable them maintain their living standard. It could, therefore, be said that, the high-pay job and opportunities to employment after school were the main driving force and have more weight when making a decision on the choice of business studies among senior high students in the WaMunicipality of the Upper West Region of Ghana.

The second most influential extrinsic factor according to the respondents in their choice of business studies as a programme of study was easy access to employment when they graduate from school with a mean score of 3.19 and a standard deviation of 0.81 . This finding was supported by Rudhumbu, Tirumalai and Kumari (2017) who conducted a study of 300 undergraduate students' participants of Botho University that employment prospects of graduateswere the major consideration of students and hence factor that influenced them to choose the university. Pascual (2014) added that the students' first consideration in choosing a course in college is the availability of possible work. Again, a study conducted by Greenberg and Baron (2008) maintained that individuals favour occupations in which there is bigger likelihood of career opportunities and would rather avoid occupations in which opportunities are limited or on decline. Closely following the hope of getting employment after graduation is peer influence which has a mean score of 3.00 and standard deviation of0.72. This meant thatthe influence of friends and peers in making a choice of programme has a great weight in one's decision of career choice. Thisfinding support the results of Asuquo's (2011), who indicated in his study, that the peers influence affects the decision on career choice of business studies programme. Myburgh's (2005) argument that peer groups and friends have significant impact on individuals' career choices. On the contrary, Kaneez and 
Medha (2018) noticed that peer influence has less affect in choosing courses.

The broad nature of the field of business studies, parental influence and societal influence were rated as the factors with the least influenceon high school student's choice of business programmewith a means score of $1.64,2.24$, and 2.57 and standard deviations of $0.50,0.55$, and 0.67 respectively. The respondents indicated clearly that these factors had less influence on their decision to select the business programme at the senior high school. This view was contrary to views ofIgbinedion (2011) who indicated that Nigerian male students perceived parental influence as a factor that influenced their choice of a secretarial career, which is more inclined towards female students. Similarly, Agarwala (2008) established that Indian fathers were found to have most significant influence in the career choices of Indian boys and girls in business management. Myburgh's (2005) also argued that parentshave significant impact on individuals' career choices. The findings of this current study on parental influence fails to agree with the earlier studies as reported, which means parents do not influence the choice of programme their wards chose.

Gender Influence on the Choice of Business as a Programme of Study in the Senior High Schools

Table 3: T-test Analysis of Gender influence on choice of Business Studies

\begin{tabular}{|c|c|c|c|c|c|c|}
\hline $\begin{array}{c}\text { Responden } \\
\text { ts }\end{array}$ & $\begin{array}{c}\text { No } \\
\text {. }\end{array}$ & Mean & SD & $\begin{array}{c}\text { Calcula } \\
\text { ted t }\end{array}$ & Df & Sig (2-tailed) \\
\cline { 1 - 4 } Males & 60 & 15.33 & 3.65 & & & \\
\cline { 1 - 3 } Females & 35 & 12.92 & 2.19 & 1.21 & 93 & 0.22 \\
\hline
\end{tabular}

Source: Field Survey, 2018; Independent sample t-test significant at 0.05

The last aspect of the study sought to examine whether gender has any significant influence on the choice of business studies. The result of the independent $t$-test analysis indicated that there is no significant difference between males and females in their choice of programme. This is because the calculated $t$ value of (1.21) is less than the critical value of (1.96) while the $\operatorname{sig}(2$-tailed) value of $(0.22)$ is greater than the 0.05 level of confidence The result therefore revealed that there is no significant difference between males $(M=15.33, S D=3.65)$ and females $(M=12.92, S D=2.19)$ on the choice of business studies programme as indicated in Table 3. It can, therefore,beconcluded that both males and females' decision on the choice of business studiesas a programme of study is largely based on self-interest and future educational progression instead of their gender. This finding is in line with Chileshe and Haupt (2010) that there is no significant difference in gender in relation to making a choice of programme in a study conducted in South Africa, they found that both male and female students are motivated by perceived salary, working conditions, opportunities for promotion and lifelong learning. Also, Dolado and Morales (2009) found in their study thatseveral factors were responsible for the gender differences in pursuing educational programmes. These include social-cultural, economic, environmental and academic factors, but not really the gender of the individual. However, Kaur and Leen (2007) put forth a contrary view when they state that students' choices of major courses are influenced by factors such as gender.

The major finding of the present study is that the choice of business studies as a programme is influenced by many factors which are classified thematically into intrinsic factors and extrinsic factors. The most influential intrinsic factors that propel senior high schoolstudents to make a choice of business studies as a programme of study were the selfinterest and ability to progresson the educational career from senior high school to tertiaryinstitutions. On the other hand, the hope of securing high-pay jobs in the future and opportunities for easy employment are the most influential extrinsic factors that are associated with the business studies profession.however, there is no significant difference in gender on making a choice of business studies programme in the senior high schools. This implies that one's gender do not determine his or her decision in making a choice of programme.

\section{IV.CONCLUSIONS}

The study has contributed to the literature by enhancing our understanding of the factors that influence students' choice of programme in Ghana and especially in the WaMunicipality of the Upper West Region of Ghana. The study empirically discovered that the most influential intrinsic factors that propel senior high school students to make a choice of business studies as a programmewere the self-interest (motivation) and future educational progression from high school to tertiary institution. On the basis of these findings, we concluded that the self-interest is the most influential factor on the part of senior high school students in their decision to select or choose a programme of study. The opportunity to continueone's education to tertiary level institutions such as colleges of education and nursing colleges after pursuing business studies programme also has a greater influence on senior high school student's choice of a programme.

Another conclusion drawn from the findings of the study was that, the most extrinsic factors that influence senior high school students to choose business studies as a programme of study werethe possibility of getting high-pay jobs and opportunities for getting employment as compared to other programmes. This is because the students preferred high-pay jobs such as accountancy, banking, financial controller, auditing, among others careers, in order to earn better and maintain good standard of living. The last conclusion we drew from the findings of the study was that there is no significant relationship between gender and the choice of business studies as a programme of study.This means that the choice of an educational programme is not depended on one's gender but rather on the interest, motivation, prestige and jobs prospects that the individuals hold. 


\section{RECOMMENDATIONS}

Based on the findings of the study and the conclusions drawn, the researchers have made the following recommendations. First of all, students should be given the independence to make a choice of a programmeof study based on the areas of their interests. Parents and teachers should only guide andfacilitate students to choose programmes of study based on the areas of their interest rather than imposingprogrammes on the students. Parents should not force their wards to pursue their preferred occupations programmes. Second, educational authorities should continue to design their curricula based on the interests of the students, the society and the accounting standards. The business education curricula should incorporate the developmental and social interests of the learners in order to gain the interests of students in learning the curricula.

Again, it is recommended that all educational institutions, including universities, nursing training colleges and colleges of education, should allow unrestricted equal opportunity to all high school graduates, including business studies graduates, to further their education after completing high school. The current practice of denying business studies graduates admission intoprogrammes at the Nursing and the Teacher Training Colleges should be revised. Lastly, more exposure should be given to high school students to interact with business professional bodies so as to understand thedemands, employment opportunities and requirements of the business studies programmes.

\section{REFERENCES}

[1] Abdullahi, S.,\&Bukar, R. A. (2000). Gender difference and career interest of undergraduate: Implication for career choice. European Journal of Scientific Research, 26 (3), 461-469.

[2] Agarwala, T. (2008). Factors influencing career choice of management students in India. Career Development International, 13(4), 362-376.

[3] Ahmed, K.A., Sharif, N. \& Ahmad, N. (2017). Factors influencing student's career choice: Empirical evidence from business students. Journal of Southeast Asia Research, 1-15.

[4] Amoor, S.S., (2010). The need to improve teacher quality in business education in Nigerian Universities.International Journal of Education Research 11(1), 1-11.

[5] Asuquo, A. I. (2011). Factors that influence accounting as career choice of Nigerian university students in the 21 st century. The Certified National Accountant, 6(1) 34-38.

[6] Auyeung, P.,\& Sands, J. (2006) factors influencing accounting students' career choice: a cross-cultural validation study. Accounting Education, 6(1), 13-23.

[7] Bryne, M., \& Willis, P. (2005). Irish secondary students' perception of the work of accountants and the accounting profession. Accounting Education, 14(1), 367-381.

[8] Carbonaro, W. (2005). Tracking students' effort and academic achievement. Sociology of Education, 78(1), 27-49.

[9] Chileshe, N. \&Haupt, T. C. (2010). An empirical analysis of factors impacting career decisions in South African construction industry. Journal of Engineering Design and Technology, 8(2), 221-239.
[10] Cohen, J., \& Hanno, D. (1993). An analysis of underlying constructs affecting choice of accounting as a major. Issues in Accounting Education, 8 (2), 219-238.

[11] Colom, R., \& Lynn, R. (2004). Testing the development theory of sex differences in intelligence on 12-18 years old. Personality and Individual Differences, 36, 75-82

[12] Crews, J. W.,\& Dickerson, J. Z. (1999) Curriculum development in education for business. National business education year book. US: Central Library.

[13] Dolado, J., \& Morales, E. (2009). Which factors determine academic performance of economics fresher's? Some Spanish evidence. Investigations Economies, 33(2), 179-210.

[14] Eccles, J.S., Wigfield, A., Harold, R. D., \&Blumenfeld, P. C. (1993). Age and gender differences in children's self and task perceptions during elementary school. Child Development Journal $64,830-847$.

[15] Greenberg, J.,\& Baron, R.A. (2008). Behaviours in organizations: Understanding and managing the human side of work. India, Oklahoma State University

[16] Igbinedion, V. I. (2011). Perception of factors that influence students' vocational choice of secretarial studies in tertiary institutions in Edo State of Nigeria. Retrieved from https://www.semanticscholar.org/paper/perception-of-factors-thatinfluencestudents\%27-ofIgbinedion/70c8f8a7ef48c2db495595e49ced8444791d8cd5.

[17] Joseph, G. P. (1982). An empirical analysis of career choice factors among accountants, attorneys, engineers and physicians. Accounting Review, 57 (4), 785-793.

[18] Kaneez, B.-S. \&Medha, K. (2018). Factors influencing grade 10 students' career choice in Mauritius. International Journal of Academic Research in Progressive Education and Development, 7(2), 30-44.

[19] Kaur, M., \&Leen, E. Y. (2007). Factors influencing undergraduates' choice of business major. India:INTI International University College

[20] Kim, D. \& Markham, F. S. (2002). Why students pursue the business degree: A comparison of business majors across universities. The Journal of Education for Business, 78(1), 28-32, http://dx.doi.org/10.1020/08832320209599694

[21] Malgwi, C. A., Howe, M. A., \& Burnaby, P. A. (2005). Influences on student's choice of college major. Journal of Education for Business, 80 (5), 275-285.

[22] Maudlin, S., Crain, J. L., \&Mounce, P. H. (2000). The accounting principles: instructor's influence on student's decision to major in accounting. Journal of Education for Business, 75 (2), 142-148.

[23] Myburgh, J. (2005). An empirical analysis of career choice factors that influence first year accounting students at the University of Pretoria: A cross racial study. Meditarian Accounting Research, 13 (2), 35-48.

[24] Osei-Marfo, G. (2014, August 21). Challenges facing business education in Ghana; The way forward. Ghana News Agency, P. 2.

[25] Osuala, E.C., (2004). Principles and methods of business and computer education. Enugu State: Cheston Agency Ltd.

[26] Paolillo, J.,\& Estes, R. (1982). An empirical analysis of career choice factors among accountants, attorneys, engineers and physicians. The Accounting Review, 62(30) 785-793.

[27] Pozo, S., \& Stull, C. (2006). Requiring a mathematics skill unit: Result of a randomized experiment. American economic review, 96(2), 437-441.

[28] Rudhumbu, N., Tirumalai, A. and Kumari, B. (2017). Factors that influence undergraduate students' choice of a university: A case of Botho University in Botswana. International Journal of Learning and Development, 7(2), 27-37.

[29] Uyar, A., \&Ali, H. G. (2011). Factors affecting students' career choice in accounting: The case of Turkish University. American Journal of Business Education, 4 (1), 29-38.

[30] Wilberg, S. \& Lynn, R. (1999). Sex differences in historical knowledge and school grades: A 26 nation study. Personality and Individual Differences, 27(2), 1221-1229.

[31] Xiang, P., Mcbride, R., Guan, J., \& Solomon, M.A. (2003). Children's motivation in elementary physical education: an 
expectancy-value model of achievement choice. Research Quarterly for Sport and Exercise, 74, 25-35.

[32] Yaseen, W. S. (2011). Factors influencing Kuwaiti student teachers' choice of teaching as a profession. College Student Journal, 45(3),

[33] Yazici, S. \&Yazici A. (2010). Students' choice of college major and their perceived fairness of the procedure. Evidence from Turkey. Educational Research and Evaluation, 16(4), 371-382.

[34] Okiror, J.J \&Otabong, D. (2015). Factors influencing career choice among undergraduate students in an Africa University context: The Case of Agriculture Students at Makerere University, Uganda. Journal of Dynamics in Agricultural Research, 2(4), 12-20.

[35] Zakaria, W., Fauzi, N. A., \& and Hassan, S. F. (2012). Accounting as a choice of academic program. Journal of Business Admin Research, 1 (1), 43-52. 